Article

\title{
In Vitro Tests for a Rapid Evaluation of Antidiabetic Potential of Plant Species Containing Caffeic Acid Derivatives: A Validation by Two Well-Known Antidiabetic Plants, Ocimum gratissimum L. Leaf and Musanga cecropioides R. Br. ex Tedlie (Mu) Stem Bark
}

\author{
Abdulmomem Awwad ${ }^{1,+}{ }^{\oplus}$, Patrick Poucheret ${ }^{1, *,+}{ }^{+}$, Yanis A. Idres ${ }^{1}$, Damien S. T. Tshibangu ${ }^{2}$, Adrien Servent ${ }^{1}$, \\ Karine Ferrare ${ }^{1}$, Françoise Lazennec ${ }^{1}$, Luc P. R. Bidel ${ }^{3} \mathbb{D}$, Guillaume Cazals ${ }^{4}$ and Didier Tousch ${ }^{1}$ \\ check for \\ updates \\ Citation: Awwad, A.; Poucheret, P.; \\ Idres, Y.A.; Tshibangu, D.S.T.; Servent, \\ A.; Ferrare, K.; Lazennec, F.; Bidel, \\ L.P.R.; Cazals, G.; Tousch, D. In Vitro \\ Tests for a Rapid Evaluation of \\ Antidiabetic Potential of Plant Species \\ 1 Qualisud, University Montpellier, CIRAD, Institut Agro, Avignon Université, University de La Réunion, \\ 34090 Montpellier, France; abd.awad.fr@gmail.com (A.A.); yanidres@gmail.com (Y.A.I.); \\ adrien.servent@cirad.fr (A.S.); karine.ferrare@umontpellier.fr (K.F.); francoise.lazennec@umontpellier.fr (F.L.); \\ didier.tousch@umontpellier.fr (D.T.) \\ 2 Laboratory of Natural Substances and Medicinal Chemistry, Faculty of Sciences, University of Kinshasa, \\ Kinshasa 190 Kinshasa XI, Democratic Republic of the Congo; tshibangud@gmail.com \\ 3 INRA, UMR AGAP, CIRAD, SupAgro, 2 Place Pierre Viala, 34060 Montpellier, France; \\ luc.bidel@umontpellier.fr \\ 4 Guillaume Cazals, University Montpellier, IBMM UMR5247, CNRS, ENSCM, Place Eugène Bataillon, \\ CEDEX 5, 34095 Montpellier, France; guillaume.cazals@umontpellier.fr \\ * Correspondence: patrick.poucheret@umontpellier.fr; Tel.: +33-4-11-75-95-07 \\ + These authors equally contributed.
} Containing Caffeic Acid Derivatives: A Validation by Two Well-Known Antidiabetic Plants, Ocimum gratissimum L. Leaf and Musanga cecropioides R. Br. ex Tedlie (Mu) Stem Bark. Molecules 2021, 26, 5566. https://doi.org/10.3390/ molecules26185566

Academic Editors: Letizia Bresciani and Anna Tresserra-Rimbau

Received: 29 July 2021

Accepted: 6 September 2021

Published: 13 September 2021

Publisher's Note: MDPI stays neutral with regard to jurisdictional claims in published maps and institutional affiliations.

Copyright: (c) 2021 by the authors. Licensee MDPI, Basel, Switzerland. This article is an open access article distributed under the terms and conditions of the Creative Commons Attribution (CC BY) license (https:// creativecommons.org/licenses/by/ $4.0 /)$.
Abstract: Plant bioactive extracts represent a major resource for identifying drugs and adjuvant therapy for type 2 diabetes. To promote early screening of plants' antidiabetic potential, we designed a four in vitro tests strategy to anticipate in vivo bioactivity. Two antidiabetic plants were studied: Ocimum gratissimum L. (Oc) leaf extract and Musanga cecropoides R. Br. ex Tedlie (Mu) stem bark extract. Chemical compositions were analyzed by LCMS and HPLC. Antidiabetic properties were measured based on (1) INS-1 cells for insulin secretion, (2) L6 myoblast cells for insulin sensitization (Glut-4 translocation), (3) L6 myoblast cells for protection against hydrogen peroxide $\left(\mathrm{H}_{2} \mathrm{O}_{2}\right)$ oxidative stress (cell mortality), and (4) liver microsomial fraction for glucose-6-phosphastase activity (G6P). Oc extract increased insulin secretion and insulin sensitivity, whereas it decreased oxidative stressinduced cell mortality and G6P activity. Mu extract decreased insulin secretion and had no effect on insulin sensitivity or G6P activity, but it increased oxidative stress-induced cell mortality. Results were compared with NCRAE, an antidiabetic plant extract used as reference, previously characterized and reported with increased insulin secretion and insulin sensitivity, protection against oxidative stress, and decreased G6P activity. The proposed set of four in vitro tests combined with chemical analysis provided insight into the interest in rapid early screening of plant extract antidiabetic potential to anticipate pharmaco-toxicological in vivo effects.

Keywords: Ocimum gratissimum; Musanga cecropioides; in vitro antidiabetic; insulin secretion; glucose uptake; protection cells against $\mathrm{H}_{2} \mathrm{O}_{2}$ oxidative stress; caffeoyl derivatives

\section{Introduction}

Type 2 diabetes (T2D) is a metabolic disorder characterized by uncontrolled chronically high glucose levels. It is now admitted that chronic oxidative stress and low grade chronic inflammation are associated with the insulin resistance of insulin-sensitive tissues, e.g., skeletal muscles, liver, and adipose tissue [1]. Under this environmental imbalance, the $\beta$ cells are subjected to a glucose toxicity effect as well as to oxidative stress, inflammation 
stress, endoplasmic reticulum stress, and amyloid stress, leading to abnormal insulin secretion and cell death in the long term $[2,3]$.

To treat T2D, oral pharmacological antidiabetic allopathic drugs are prescribed in order to reduce hyperglycemia. These drugs include insulin secretagogue agents (sulfonylureas, glinides), insulin-sensitizing agents (metformin), and glucose absorption inhibitors such as $\alpha$-glucosidase inhibitors (acarbose, miglitol). Although these drug molecules are used effectively, none of them are simultaneously targeting oxidative stress/chronic inflammation and insulin resistance.

In this context, plant extracts represent a potential adjuvant therapy as food supplements or health foods [4]. The hydroxycinnamic acids, including caffeic derivatives such as chlorogenic and chicoric acids, possess antidiabetic effects. They combine antiinflammatory activity with protection against oxidative stress and cytotoxic injuries, but also provide insulin-sensitizing properties to tissues and/or an insulin-secreting effect [5-11]. In a previous work, we studied a caffeic derivatives extract from Chicorium intybus L. root (NCRAE) containing a high CRA (chicoric acid) content. It was investigated using four in vitro tests. We showed that NCRAE (at a concentration range of $10-100 \mu \mathrm{g} \cdot \mathrm{mL}^{-1}$ ) was able to increase insulin secretion of INS-1 cells, increase the insulin sensitization of L6 myoblast cells [8], protect the L6 cells against an oxidative $\mathrm{H}_{2} \mathrm{O}_{2}$ stress, and decrease the glucose-6-phosphatase (G6Pase) activity in rat liver microsomes [10]. The NCRAE in vitro effects were correlated with an in vivo antidiabetic effect [11].

Based on our NCRAE results, we intended to study the pertinence of a set of four in vitro tests, using a single dose of $50 \mu \mathrm{g} \cdot \mathrm{mL}^{-1}$ concentration, in order to assign or not an antidiabetic potential to a plant extract. Thus, to avoid in vivo test burden, this one shot strategy could allow a greater efficiency in screening the antidiabetic potential of a large collection of extracts.

Among the candidate plants known for their antidiabetic effects and caffeic derivatives contents, we used Ocimum gratissimum L. (Lamiaceae family) and Musanga cecropioides R. Br. ex Tedlie (Cecropiaceae family). In vivo studies demonstrated that Oc leaf extracts possess both in vitro and in vivo hypoglycemic properties [12-19]. Recently, Musanga cecropioides $(\mathrm{Mu})$ leaves or stem bark extracts have shown an antidiabetic potential [20-24]. A Mu leaf extract exhibited an anti-inflammatory effect in a specific animal model [25]. The chemical analysis of Ocimum gratissimum content demonstrated the presence of some caffeic derivatives with caffeic, caftaric, and chicoric acids being the most abundant $[19,26]$. In Musanga cecropioides, the presence of chlorogenic acid was also revealed [27,28].

Our approach was to investigate the in vitro effects of extracts from Ocimum gratissimum and Musanga cecropioides in comparison with previous results obtained with Cichorium intybus extract (NCRAE). After chemical analysis of the caffeic derivatives content was realized, the in vitro investigations were carried out: (i) insulin secretion test on INS-1 cells, (ii) glucose uptake evaluation of L6 muscle cell, (iii) cell protection test against $\mathrm{H}_{2} \mathrm{O}_{2}$ oxidative stress in L6 cells, (iv) glucose 6-phosphatase (G6Pase) activity in hepatic microsomal fraction.

\section{Results}

Results were obtained following the workflow diagram presented hereafter (Figure 1). 


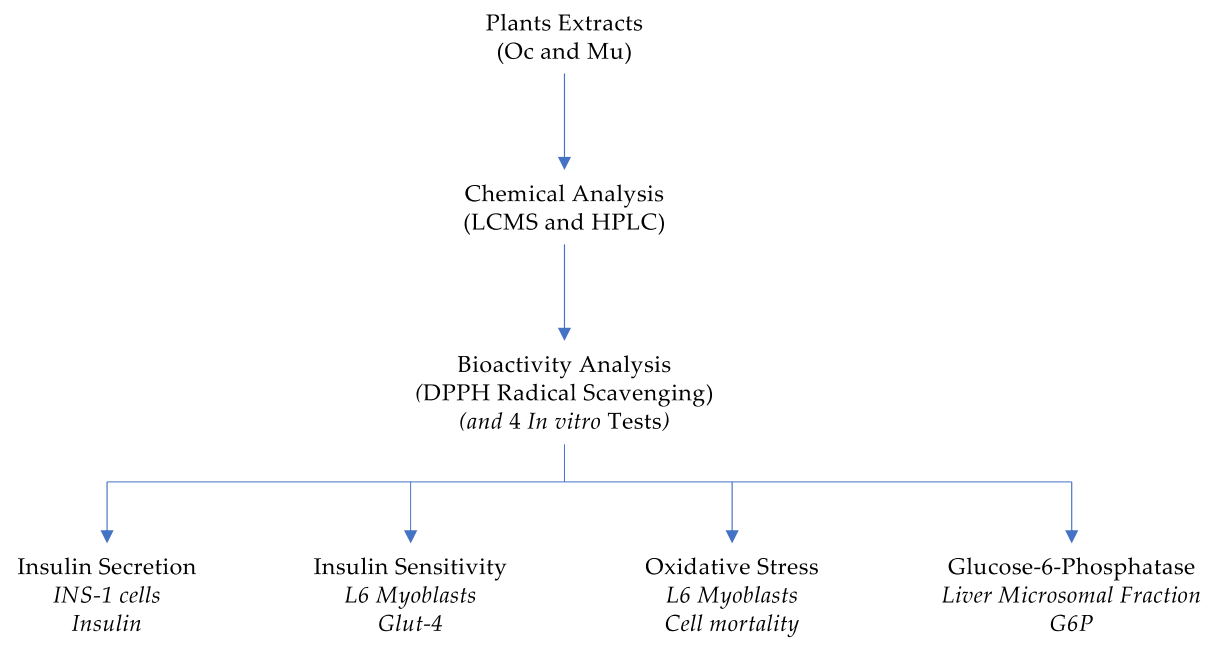

Figure 1. Workflow diagram.

\subsection{Chemical Analysis of Oc and $M u$ \\ 2.1.1. LC-MS Analysis}

Oc extract had three major peaks, corresponding to chicoric acid (P30), rosmarinic acid $\left(\mathrm{P} 30^{1}\right)$, and tri-caffeoylquinic acid isomer (P32), in accordance with previous publications $[19,26]$. In addition, this extract had three apigenin glycoside derivatives (P12, P14, P16)) with the shared fragment $\left.\left(\mathrm{m} / \mathrm{z}[\mathrm{M}+\mathrm{H}]^{+}\right)=409[\mathrm{M}+\mathrm{H}]^{+}\right)$and minor peaks corresponding to flavones derivatives luteolin (P6) and apigenin glycosides, as reported [29]. Finally, the extract was rich in one dihydroxybenzoic acid-(P3), as expected [30]. The extraction and purification process strongly depleted the more hydrophilic compounds of leaves of Ocimum basilicum previously described (gallic acid, gallic acid methyl ester, gallic acid ethyl ester, 3,4-dihydroxybenzoic acid, 4-hydroxybenzoic acid, 4-hydroxybenzaldehyde, gentisic acid, vanillic acid, caffeic acid). Some additional hydrophobic compounds previously described were also found at trace level ( $p$-coumaric acid, ferulic acid, circiliol, cirsimarin, cirsilineol, acacetin, eryodictyiol-7-O-glucoside, eugenol) [30].

The chemical analysis of Mu stem bark extract was in accordance with the literature $[27,28,31]$. In the minor peaks, four hydroxycinnamic acids were identified (P10, P23, P25 to P32), most notably chlorogenic acid (P10) and caffeoyl tartaric acid or caftaric acid (P23). Three dihydroxybenzoic acids were found (P1, P2, P3, P4) with the protocatechuic acid (P1) being the most abundant, as previously described [28]. The 2,3dihydroxybenzaldehyde (P5) was also found (at $5.8 \mathrm{~min}, 8.7 \mathrm{~min}$, and $17.5 \mathrm{~min}$ ). The $\mathrm{Mu}$ extract contained two major peaks, exhibiting absorbance spectrum of apigenin (P12 and P15). The first (maxima at 269.9 and $335.9 \mathrm{~nm}$, with $m / z=593[\mathrm{M}-\mathrm{H}]^{-}$, had fragments ions $m / z=431$, and $269[\mathrm{M}-\mathrm{H}]^{-}$) was identified as an apigenin di-hexoside (apigenin 6,8di-C-glucoside) (P12). The second (maxima 270.9 and $337.9 \mathrm{~nm}$, with $m / z=563[\mathrm{M}-\mathrm{H}]^{-}$, and fragments ions 431 and 269) was tentatively assigned to an apigenin-C-pentosylC-hexoside (P15). Eight minor flavonoidic pics shared a typical absorbance spectrum of apigenin (P13, P15, P18 to P22, P24). In the case of P21 and P22, the two fragments $m / z=341$ and 311 corresponded to fragments $[\mathrm{M}-\mathrm{H}-120-30]^{-}$and $[\mathrm{M}-\mathrm{H}-120]^{-}$, respectively and were characteristic of the cleavage of one glycosyl moiety. Their fragment $m / z=269[\mathrm{M}-\mathrm{H}-164]^{-}$corresponded to the aglycone [Apigenin- $\left.\mathrm{H}\right]^{-}$. They corresponded to apigenin-8-C-glucoside (vitexin, P21) and apigenin-6-C-glucoside (isovitexin, P22), already found in stem bark of Musanga [28]. In positive mode, these compounds formed fragments shared by both vitexin and isovitexin $(\mathrm{m} / \mathrm{z}=121,259,283,284,313$, $\left.314[\mathrm{M}+\mathrm{H}]^{+}\right)$, and two major fragments $m / z=337$ and $415[\mathrm{M}+\mathrm{H}]^{+}$, which are described as solely specific to isovitexin fragmentation and corresponding to $[\mathrm{M}+\mathrm{H}-18]^{+}$and $[\mathrm{M}+\mathrm{H}-96]^{+}$in accordance with a previous report [31] (Table 1). 


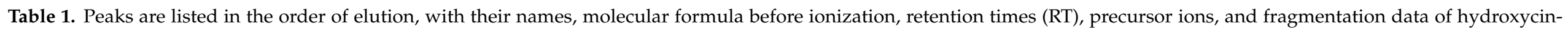

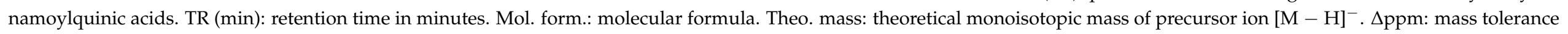
expressed in parts per million.

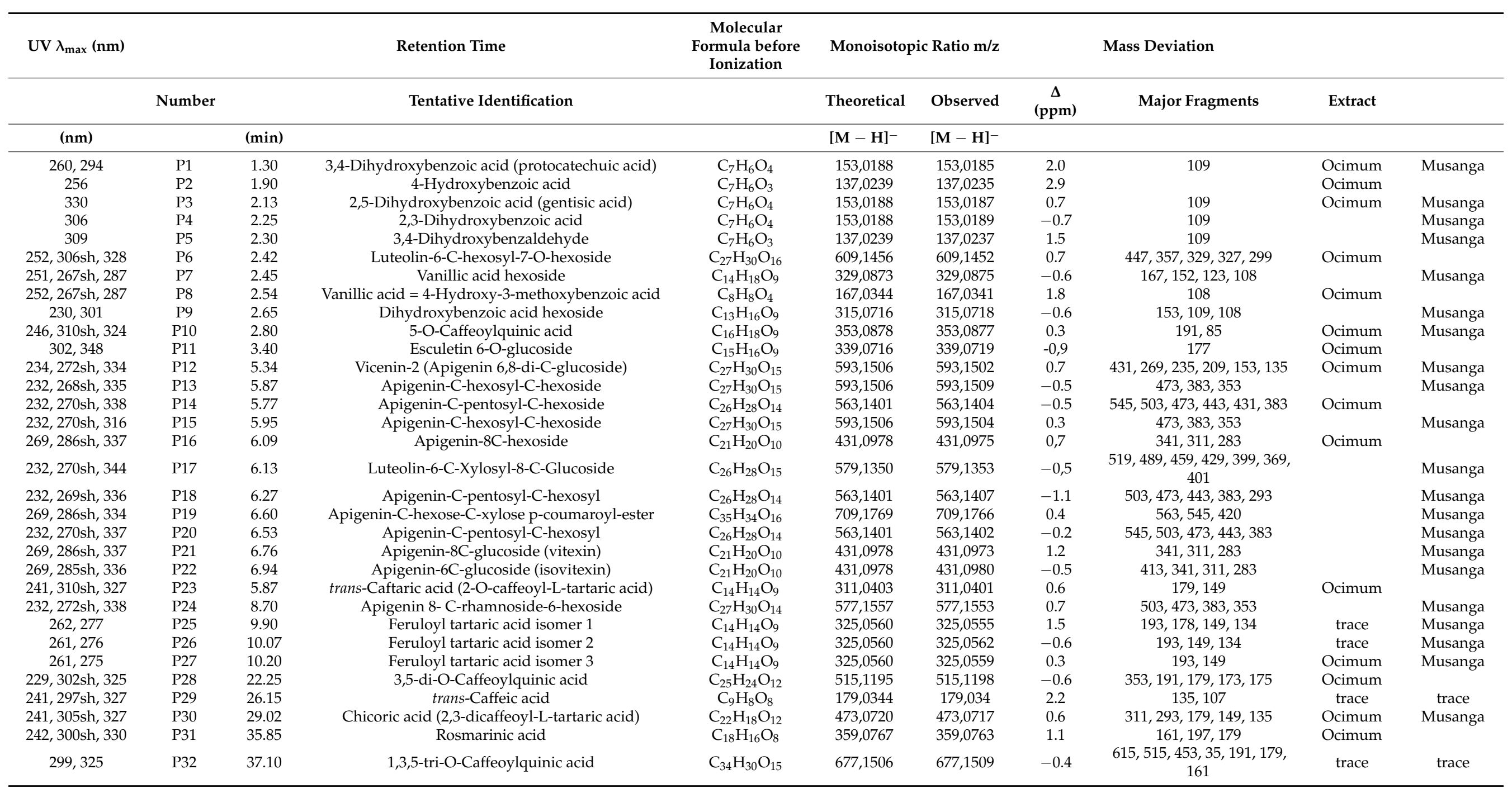




\subsubsection{HPLC Analysis}

HPLC analysis allowed evaluation of the percentage of caffeic derivatives in the two extracts. We found in Oc (Figure 2A) and Mu (Figure 2B), respectively: $0.21 \%$ and $0.08 \%$ of chlorogenic acid, $0.2 \%$ and $0.12 \%$ of caffeic acid, $0.01 \%$ and $47 \%$ of apigenin or derivatives. Oc contained $1.2 \%$ of chicoric acid. No chicoric acid was detected in Mu even though caffeoyl tartaric acid was detected by LC-MS (Figure 2).

$\mathbf{A}$

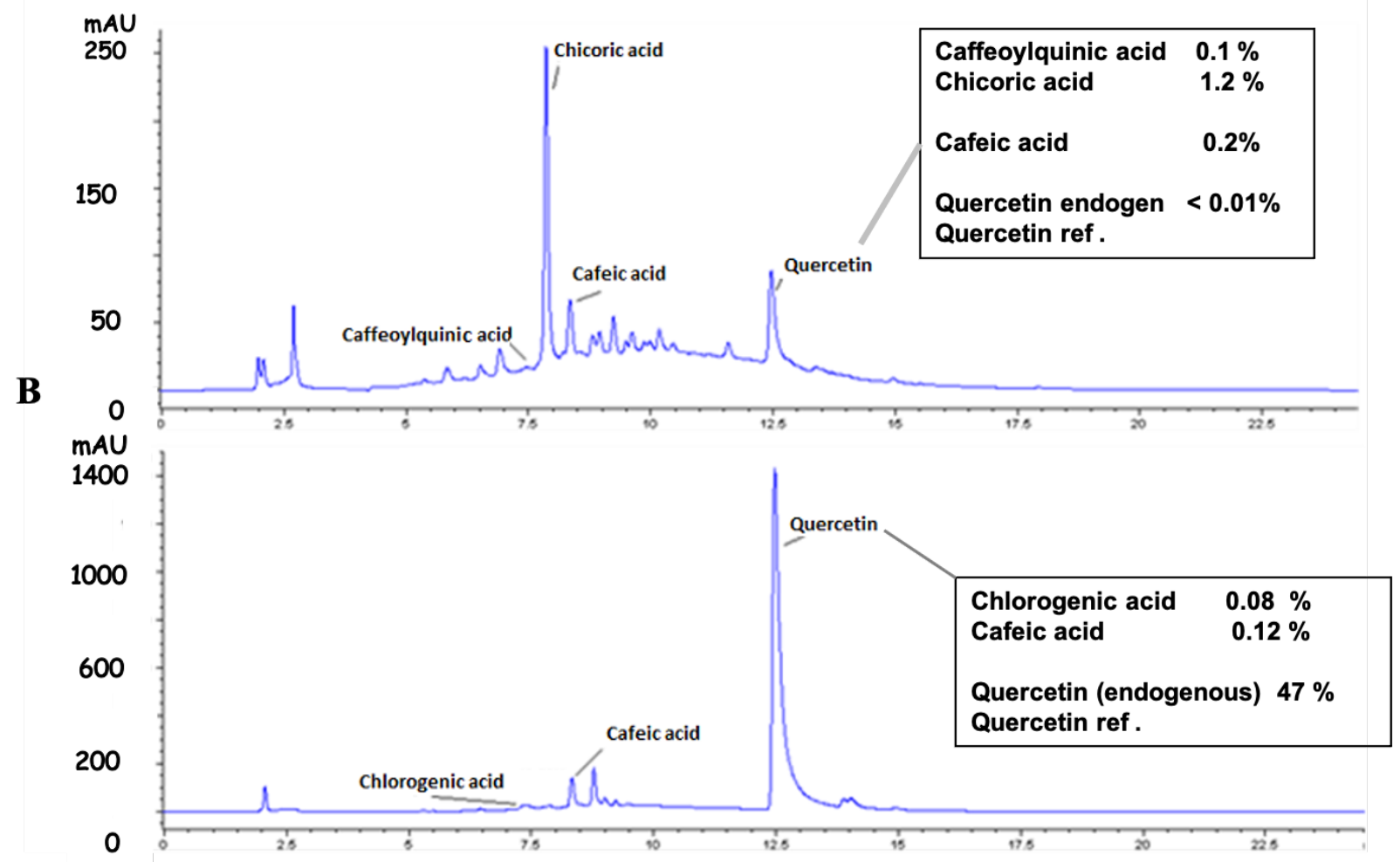

Figure 2. Quantification of caffeoyl derivatives in Oc and Mu leaves extracts by HPLC. (A) chromatogram obtained with Ocimum gratissimum L. extract (Oc). (B) chromatogram obtained with Musanga cecropoides R. Br. ex Tedlie (Mu). A standard solution containing chlorogenic acid, caffeic acid, and chicoric acid at $10 \mu \mathrm{M}$ each were used as peak area references. A $5 \mu \mathrm{M}$ external quercetin marker was subsequently added to Oc and Mu extracts to normalize the data analysis. The high uptick found in $\mathrm{Mu}$ represents both quercetin (the endogene part and the reference added) and probably the apigenin contents in Mu extract.

\subsubsection{DPPH Free-Radical Scavenging Capacities of Oc and Mu Extracts}

The DPPH free-radical scavenging capacities, expressed as QE. $\mathrm{mg}^{-1}$ for Oc and $\mathrm{Mu}$ extracts, were respectively $615 \pm 15 \mathrm{nmoles} \cdot \mathrm{mg}^{-1}$ and $1900 \pm 15 \mathrm{nmoles} \cdot \mathrm{mg}^{-1}$. In comparison, the Quercetin $\mathrm{IC}_{50}$ was $20 \mu \mathrm{g} \cdot \mathrm{mL}^{-1}$, whereas we obtained an $\mathrm{IC}_{50}$ at $30.9 \pm 1.5 \mu \mathrm{g} \cdot \mathrm{mL}^{-1}$ and $9.97 \pm 0.9 \mu \mathrm{g} \cdot \mathrm{mL}^{-1}$ for Oc and Mu extracts, respectively.

\subsection{Oc and $M u$ In Vitro Effects}

\subsubsection{Insulin Secretion Evaluations}

Insulin release by INS-1 $\beta$ cells displayed a clear and normal glucose dependency from 5.6 to $11 \mathrm{mM}$ glucose concentration. In the presence of $5.6 \mathrm{mM}$ glucose, Oc extract $\left(50 \mu \mathrm{g} \cdot \mathrm{mL}^{-1}\right)$ induced a significant increase in insulin secretion $(p<0.05)$. In contrast, Mu extract $\left(50 \mu \mathrm{g} \cdot \mathrm{mL}^{-1}\right)$ generated a drop in insulin secretion $(p<0.01)$. Positive control, tolbutamide $(100 \mu \mathrm{M})$, provoked a clear increase in insulin release $(p<0.01)$ as expected. NCRAE $\left(50 \mu \mathrm{g} \cdot \mathrm{mL}^{-1}\right)$ induced an equivalent insulin secretion when compared with Oc extract (Figure 3A). 
A

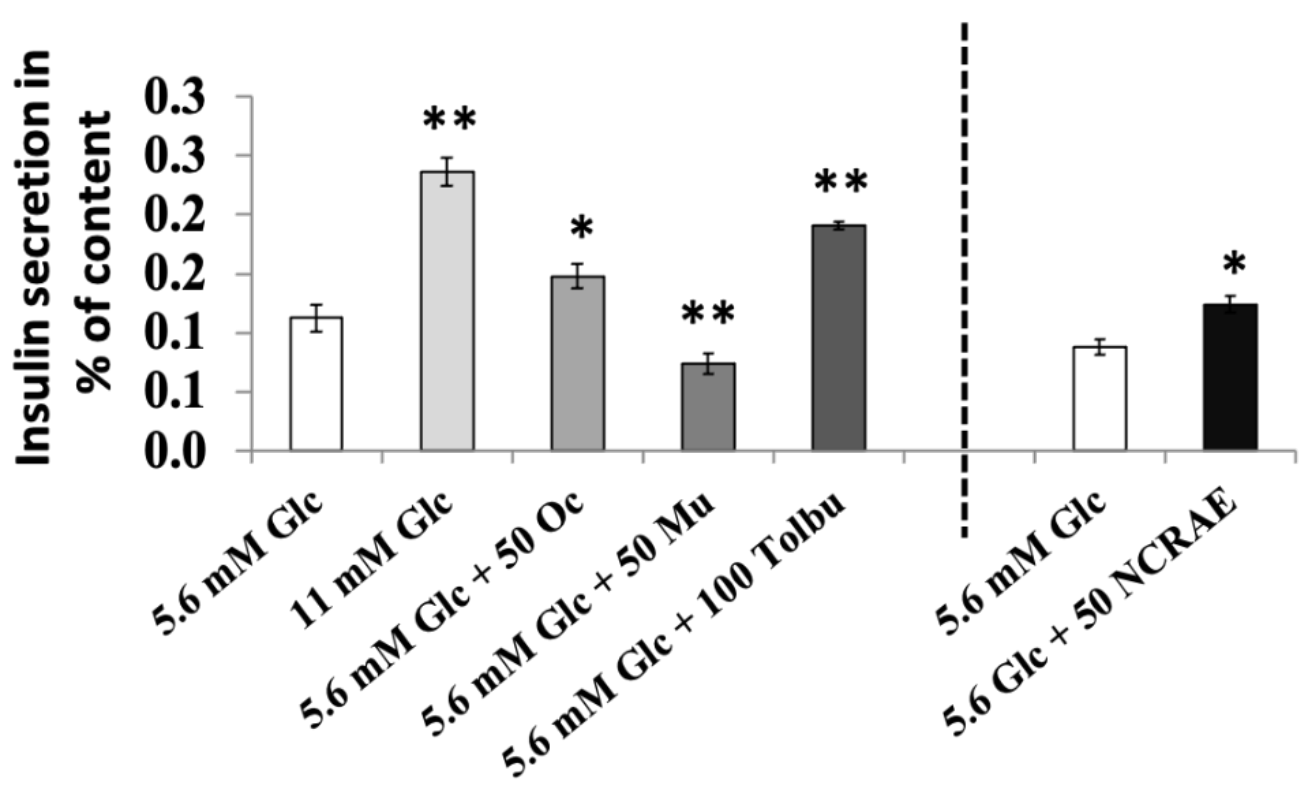

B

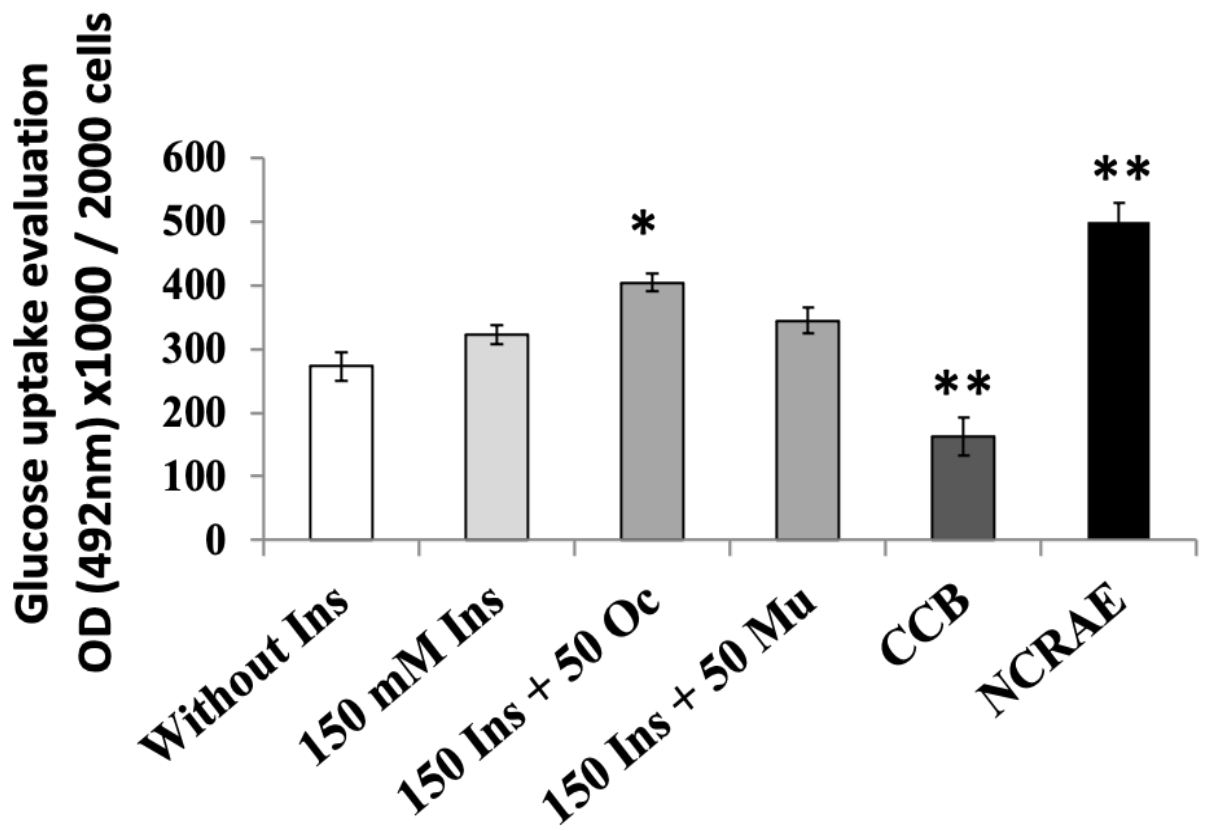

Figure 3. Insulin release and glucose uptake effects of Oc extract or Mu extract. (A) Insulin release of INS1 $\beta$ cells in the presence of $5.6 \mathrm{mM}$ glucose, with or without $50 \mu \mathrm{g} \cdot \mathrm{mL}^{-1}$ of extracts (Oc and $\left.\mathrm{Mu}\right)$. Comparison with NCRAE (reference extract) and tolbutamide as control. Values are the means $( \pm \mathrm{SD})$ of three independent experiments $\left({ }^{*} p<0.05\right.$ and $\left.{ }^{* *} p<0.01\right)$. (B) Glucose uptake evaluation of L6 muscles cells in the presence of $150 \mathrm{nM}$ insulin, with or without $50 \mu \mathrm{g} \cdot \mathrm{mL}^{-1}$ of extracts. Comparison with NCRAE and cytochalasin B (CCB) as positive control. Values are the means $( \pm \mathrm{SD})$ of ten independent experiments. ( $p<0.05$ and ${ }^{* *} p<0.01$.). 


\subsubsection{Insulin Sensitizing Evaluations}

As expected, in the presence of $150 \mathrm{nM}$ insulin, GLUT4 quantification on the membrane cell of L6 cells was higher than controls. The addition of Oc extract at a concentration of $50 \mu \mathrm{g} \cdot \mathrm{mL}^{-1}$ significantly increased GLUT4 transporters' presence in the membrane $(p<0.05)$. At the same concentration, Mu extract did not significantly modify GLUT4 quantification. As expected, the reference inhibitor, cytochalasin (CCB), effectively reduced the translocation of GLUT4 to the membrane $(p<0.01)$. NCRAE induced the highest increase in GLUT4 transporters toward the membrane ( $p<0.01$, Figure 3B).

\subsubsection{Hepatic Glucose 6-Phosphatase Activity}

G6Pase activity was measured on rat microsomal hepatic fraction. Oc extract (50 $\left.\mu \mathrm{g} \cdot \mathrm{mL}^{-1}\right)$ induced a clear inhibitory effect $(p<0.05)$. At the same concentration, $\mathrm{Mu}$ extract did not significantly modify this activity, despite the significant CGA content, suggesting that the potential presence of other(s) molecule(s) counteracting CGA effects, as hypothesized in the Discussion. Likewise, NCRAE did not influence hepatic G6Pase, whereas chlorogenic acid (CGA) at $50 \mu \mathrm{g} \cdot \mathrm{mL}^{-1}$ induced a significant decrease of G6P activity $(p<0.05$, Figure $4 \mathrm{~A})$.

\section{A}

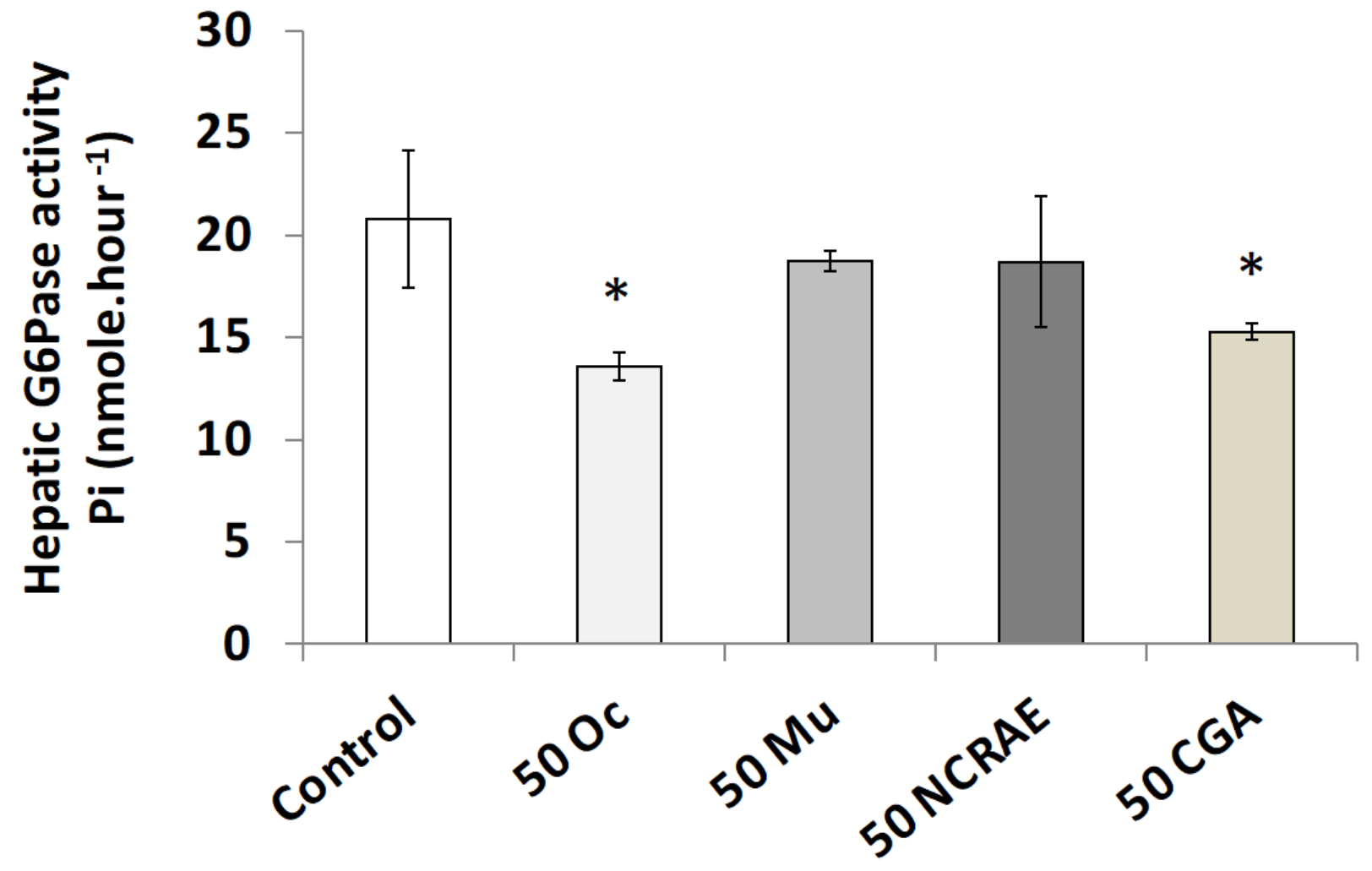

Figure 4. Cont. 


\section{B}
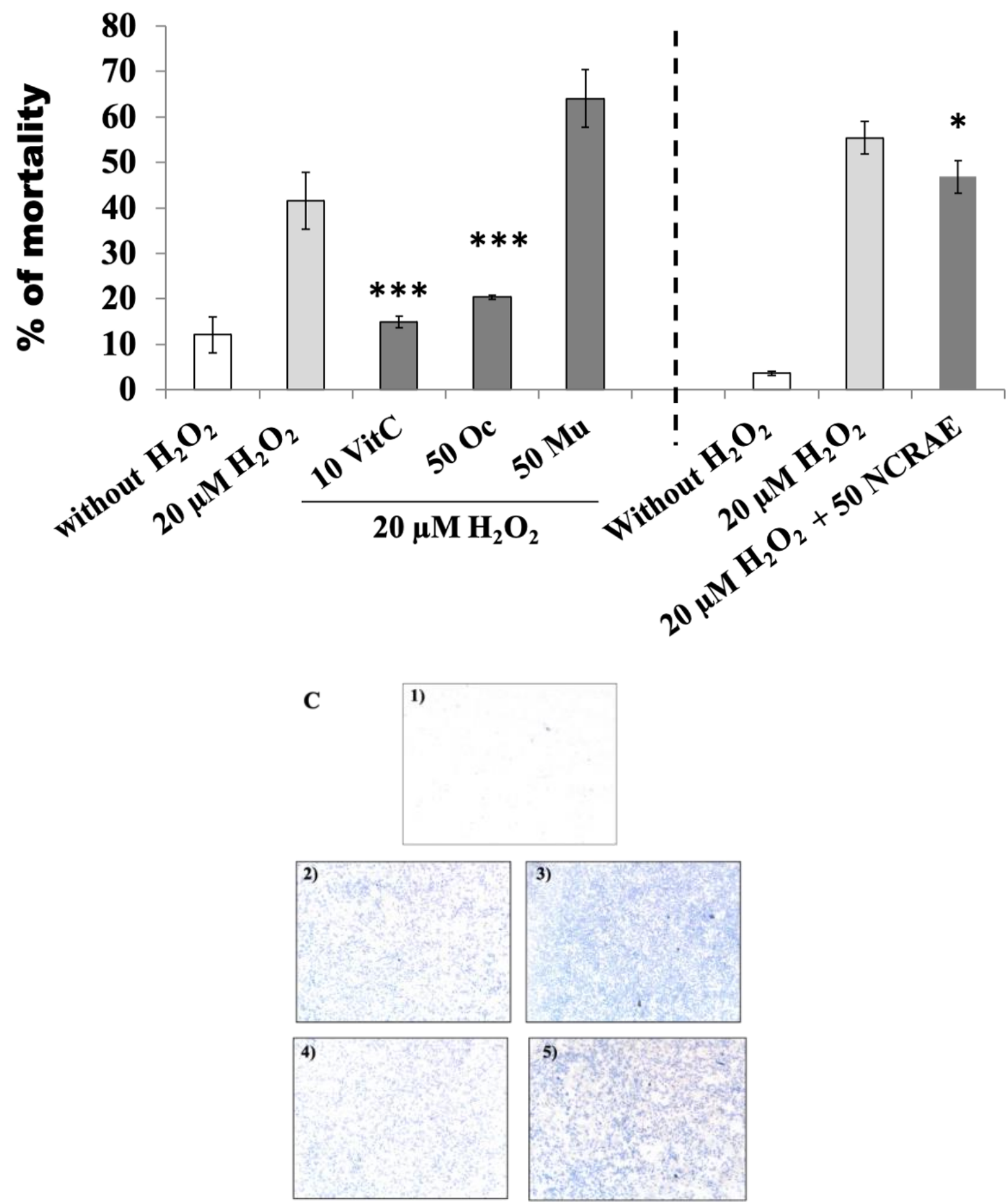

Figure 4. Modulation of the glucose 6-phosphatase activity and $\mathrm{H}_{2} \mathrm{O}_{2}$ oxidative stress effects of Oc extract or Mu extract $\left(50 \mu \mathrm{g} \cdot \mathrm{mL}^{-1}\right)$. (A) Glucose 6-phosphatase activity on hepatic microsomes in presence of Oc and Mu extracts. Comparison with NCRAE as reference extract and chlorogenic acid (CGA) as positive control. Values are the means $( \pm \mathrm{SD})$ of three independent experiments $\left({ }^{*} p<0.05\right)$. (B) Percentage of mortality induced in L6 muscle cells by $\mathrm{H}_{2} \mathrm{O}_{2}$ oxidative stress. Comparison with NCRAE (reference extract) at $50 \mu \mathrm{g} \cdot \mathrm{mL}^{-1}$ and vitamin C (Vit C) as positive control. Values are the means $( \pm \mathrm{SD})$ of six independent tests $\left({ }^{*} p<0.05\right.$, and $\left.{ }^{* * *} p<0.001\right)$. (C) Images of L6 cells mortality after $\mathrm{H}_{2} \mathrm{O}_{2}$ oxidative stress exposure, objectivized by trypan-blue staining. (1) Control without $\mathrm{H}_{2} \mathrm{O}_{2}$; (2) with $20 \mu \mathrm{M} \mathrm{H}_{2} \mathrm{O}_{2}$; (3) with $60 \mu \mathrm{M} \mathrm{H} \mathrm{H}_{2}$; (4) Oc pretreatment and $20 \mu \mathrm{M} \mathrm{H}_{2} \mathrm{O}_{2}$; (5) $\mathrm{Mu}$ pretreatment and $20 \mu \mathrm{M} \mathrm{H}_{2} \mathrm{O}_{2}$. 


\subsubsection{Protective Effect on L6 Cells against $\mathrm{H}_{2} \mathrm{O}_{2}$ Stress}

L6 myoblast cells were submitted to a pretreatment with Oc extract or Mu extract at a concentration of $50 \mu \mathrm{g} \cdot \mathrm{mL}^{-1}$ for $12 \mathrm{~h}$. Extracts were then discarded by two consecutive washes, and $20 \mu \mathrm{M}$ of $\mathrm{H}_{2} \mathrm{O}_{2}$ oxidative treatment was applied to induce $50-60 \%$ of cells mortality. Under these experimental conditions, the Oc extract pretreatment generated a significant protective effect against $\mathrm{H}_{2} \mathrm{O}_{2}$ treatment ( $-21 \%$ mortality) versus untreated controls ( $+42 \%$ mortality). This benefic effect was equivalent to vitamin $\mathrm{C}$ (reference) at $10 \mu \mathrm{g} \cdot \mathrm{mL}^{-1}$ pretreatment. Mu extract pretreatment provoked a marked increase in L6 cells mortality $(+22.5 \%$ mortality) $(p<0.01)$. Additionally, NCRAE pretreatment demonstrated a moderate but significant protective effect $(-15 \%$ in mortality) $(p<0.05)$ was drawn (Figure 4B,C).

\section{Discussion}

Building on previous results obtained with a Chicorium intybus root extract (NCRAE), the present study designed a one shot strategy to evaluate four in vitro bioactivity tests in order to simplify the determination of the antidiabetic potential of plants.

We showed that the in vivo antidiabetic property of NCRAE on streptozotocin rats was correlated with a set of four in vitro tests and showed its ability to increase insulin secretion in INS-1 cells, to increase the insulin sensitization of L6 myoblast cells, to protect L6 cells against oxidative $\mathrm{H}_{2} \mathrm{O}_{2}$ stress, and to decrease the glucose-6-phosphatase (G6Pase) activity on rat liver microsomes.

We used two plants, Ocimum gratissimum L. leaf extract (Oc) and Musanga cecropioides R. Br. ex Tedlie stem bark extract $(\mathrm{Mu})$, well studied for their in vivo antidiabetic effects and known for their hydroxycinnamic contents. The two extracts (Oc and $\mathrm{Mu}$ ) were analyzed by LC-MS and HPLC to precisely determine their hydroxycinnamic acids contents. Oc contained higher amounts of caffeic acid derivatives than Mu extract, which contained a very high level of apigenin. In contrast, Oc contained a very low amount of apigenin. Both contained chlorogenic acid and caffeic acid but in different proportions. Only Oc contained chicoric acid, which appeared as the major caffeic derivative. The relative content of caffeic derivatives in $\mathrm{Mu}$ and Oc was much lower than NCRAE. The variability in the chemical composition of $\mathrm{Oc}, \mathrm{Mu}$, and NCRAE extracts was interesting with regard to the perspective of exploring their potential bioactivity profiles.

A DPPH free-radical scavenging experiment highlighted similar potential of all extracts.

Oc extract revealed essential in vitro activities (i) increased insulin secretion from pancreatic $\beta$-cells, (ii) increased glucose uptake of muscular L6 cells, (iii) decreased hepatic glucose 6-phosphatase activity, and (iv) clearly reduced $\mathrm{H}_{2} \mathrm{O}_{2}$ oxidative cellular stress. These results tend to demonstrate significant biological activities that may contribute to an improvement of the metabolic disorder associated with metabolic syndrome and T2D. Our results confirm the in vivo hypoglycemic effect of a Ocimum gratissimum leaf decoction in normal and streptozotocin-induced diabetic mice [19]. Additionally, as in the precedent work cited, we confirmed the presence of chicoric acid (dicaffeoyl-tartaric acid) in Oc extract.

In comparison with NCRAE, Oc revealed a clear inhibition of the G6Pase activity, which could be correlated with the presence of CGA, known for its molecular interaction with the T1 translocase of the G6Pase complex [32,33].

The cells' protection against $\mathrm{H}_{2} \mathrm{O}_{2}$ oxidative stress was also in agreement with a recent in vivo study showing that an Ocimum gratissimum leaf phenolic extract protected rats against acute inflammation and oxidative stress [18]. Likewise, an aqueous Ocimum gratissimum extract revealed antioxidant and cytoprotective activities in the presence of hydrogen peroxide-induced toxicity in human HepG2 cells [34].

Mu extract showed that it (i) inhibited $\beta$ cells' insulin secretion, (ii) had no significant effect on muscular glucose uptake, (iii) had no significant effect on G6Pase activity, and (iv) increased mortality of $\mathrm{L} 6$ cells under $\mathrm{H}_{2} \mathrm{O}_{2}$ oxidative stress. These results were not in favor 
of an antidiabetic potential of Mu. They were in contradiction with the in vivo published results. Probably the most controversial of these results was the cellular mortality induced by the extract itself. Apigenin, the most abundant compound in $\mathrm{Mu}$, was reported to reduce the survival of neoplastic cells $[35,36]$. The inhibition of $\beta$ cells' insulin secretion may be explained by the choice of INS-1 cells, which were isolated from a rat insulinoma. $\mathrm{Mu}$ extract's absence of effect on G6Pase activity, despite its CGA content could be attributed to apigenin. Indeed, apigenin was described as a membrane disturber that is able to increase its permeability [37]. The L6 cell mortality could be explained by the presence of protocatechuic acid, known for its selective cytotoxicity on malignant cells with a putative implication of oxidative stress [38].

In summary, several conclusions arise from the present study. Ocimum gratissimum leaf extract, with its specific composition profile, induced an in vitro antidiabetic response of interest. By contrast, the Musanga cecropioides stem bark extract did not manifest satisfactory responses to our in vitro tests. Contrary to NCRAE, we showed that Oc extract revealed the effect of CGA as an inhibitor of hepatic G6Pase activity. These results suggest not only the influence of an extract's composition profile on biological activity but also the complex interplay between molecules as well as the potential impact of oral absorption when comparing in vivo and in vitro results.

\section{Materials and Methods}

\subsection{Biological Material and Drugs}

Fresh leaves of Ocimum gratissimum Linn (herbarium number: 8016/R. Dechamps) and stem bark of Musanga cecropioides R. Br. ex Tedlie (herbarium number: 1161/R. Pierlot) were collected in the outskirts of Kinshasa, in district of Kimwenza. The plant material was authenticated by Mr Landu Lukebakio, botanist in the herbarium of the "Institut National des Recherches Agronomiques" (INERA), Faculty of Sciences, University of Kinshasa. A voucher specimen of each species is deposited in the herbarium of the INERA, Faculty of Sciences, University of Kinshasa (Democratic Republic of the Congo). Rat insulinoma-derived INS-1 $\beta$ cells, were kindly provided by Pr. C.B. Wollheim (Geneva, Switzerland). Rat L6 myoblasts cell-line was purchased from LGC Promochem. Rat L6Glut4-Myc Myoblasts were obtained from Dr Cabello (France) with the authorization of Dr Klip (USA). Commercial rat liver microsomes were purchased from BD Biosciences (Le Pont de Claix, France). Tolbutamide and cytochalasin B (CCB) were obtained from Sigma-Aldrich (Munich, Germany). Caffeic, chlorogenic, chicoric, and quercetin powders from Sigma-Aldrich (St. Louis, MO, USA) were used to prepare the standard solutions of each compound at $50 \mu \mathrm{M}$.

Oc and Mu extracts were purified using the method previously described [11], with modifications. Briefly, the powder of the part of plant was poured in a cellulose cartridge and placed in a $70 \% \mathrm{EtOH}$ solution. An extraction of hydrophobic compounds was performed in a separating funnel by a half volume of chloroform before drying. The powder was dissolved in $20 \% \mathrm{EtOH}$ solution.

\subsection{Chemical Analysis}

4.2.1. LC-MS Analysis

Compounds contained in Oc and Mu extracts were characterized by LC-MS using a Synapt G2-S high-definition mass spectrometry system (Waters Corp., Milford, MA, USA) equipped with electrospray ionization source to characterize the elemental composition of parent and fragment ions according to the procedure previously described [11].

\subsubsection{HPLC Analysis}

Caffeoyl derivatives, essentially chlorogenic acid, caffeic acid, and chicoric acid, were determined and quantified by HPLC coupled with DAD detector. The chromatography system used was an Agilent 1200 series (Agilent, Santa Clara, CA, USA) equipped with a Nova-pak HR C18 $250 \mathrm{~mm} \times 4.6 \mathrm{~mm} \times 5 \mu \mathrm{m}$ column (Waters, Milford, MA, USA). The 
column thermostat was set to $25^{\circ} \mathrm{C}$, and the samples were injected automatically with an auto-sampler from the same manufacturer and with the volume programmed at $20 \mu \mathrm{L}$, corresponding to $20 \mu \mathrm{g}$ of Oc and Mu extracts. The gradient was set with two phases. Phase A was composed of acetic acid 1\%. Phase B was composed of acetonitrile. The program was as follows: time 0 was $100 \% \mathrm{~A}$; from 0 to $15 \mathrm{~min} 40 \% \mathrm{~A}$ and $60 \% \mathrm{~B}$; from 15 to $18 \mathrm{~min} 20 \% \mathrm{~A}$ and $80 \% \mathrm{~B}$; from 18 to $25 \mathrm{~min} 100 \% \mathrm{~A}$. A standard mix solution containing chicoric acid, chlorogenic acid, caffeic acid, and quercetin, at $10 \mu \mathrm{M}$, each was used as a calibrator. The peak areas were determined in order to calculate the concentrations $(\mu \mathrm{M})$ of each compound and to determine the percentage in the samples. In order to normalize the quantifications of the two extracts, we added in each sample a quercetin solution at a final concentration of $5 \mu \mathrm{M}$. The quercetin peak area constituted an external marker.

\subsection{DPPH Free-Radical Scavenging Capacity}

The DPPH (2,2-diphenyl-1-picryl-hydrazyl-hydrate) test was performed as previously described [39] using 100 nmoles of DPPH by assay. The free-radical scavenging activity was defined by the $\mathrm{IC}_{50}$, i.e., the quantity of sample needed to obtain $50 \%$ of inhibition of the DPPH absorbance was evaluated using quercetin as standard $\left(\mathrm{IC}_{50}\right.$ of $\left.20 \mu \mathrm{g} \cdot \mathrm{mL}^{-1}\right)$. The results were expressed in nmoles of quercetin equivalent (QE) per $\mathrm{mg}$ of sample (dry material).

\subsection{In Vitro Tests \\ 4.4.1. Insulin Secretion Investigations}

The insulin secretion test on rat insulinoma-derived INS-1 $\beta$ cells was previously described [8]. Briefly, after 5-6 days of cell culture maintained at $37^{\circ} \mathrm{C}$ in RPMI-supplemented medium and in a $5 \%$ of $\mathrm{CO}_{2}$ chamber, cells were washed twice in glucose-free $\mathrm{KRB}-2 \% \mathrm{BSA}$ and incubated for $90 \mathrm{~min}$ in this medium. Next, cells were washed once in glucose-free KRB-2\% BSA and incubated in the same medium added by 5.6 or $11.2 \mathrm{mM}$ glucose. To the $5.6 \mathrm{mM}$ glucose was added or not added Oc and $\mathrm{Mu}$ extracts at $50 \mu \mathrm{g} \cdot \mathrm{mL}^{-1}$, with tolbutamide as control (Sigma, Germany) at $100 \mu \mathrm{M}$. Insulin released in the medium was determined by the Insulin-Kit HTRFs (Cis-Bio International, Paris, France). Fluorescence intensities were measured on an INFINITE ${ }^{\circledR}$ F500 instrument (TECAN), and results were expressed in percentage of cell contents.

\subsubsection{Insulin-Sensitizing Evaluations}

The L6 GLUT4-myc line was used to evaluate the level of GLUT4 in the cell membranes by immuno-enzymatic assay, as previously described [40], with modifications. In brief, L6-GLUT4-myc myoblasts were cultured in 96-well plates at 2000 cells/well in DMEM medium supplemented by $10 \%$ of FCS [41]. On the day of the experiment, cells were FCS starved in DMEM-0.1\% BSA at $37{ }^{\circ} \mathrm{C}$ in a $5 \% \mathrm{CO}_{2}$ chamber during $4 \mathrm{~h}$ and washed three times before being incubated one hour in KRB- $0.1 \%$ BSA, $5 \mathrm{mM}$ glucose, with or without $100 \mathrm{nM}$ insulin, in presence or not of the Oc and $\mathrm{Mu}$ extracts at $50 \mu \mathrm{g} \cdot \mathrm{mL}^{-1}$. Cells were washed once with PBS and fixed in $95^{\circ} \mathrm{C}$ EtOH during $1 \mathrm{~min}$ and washed once with $\mathrm{H}_{2} \mathrm{O}$. The cell layers were blocked with $3 \% \mathrm{BSA}$ in PBS at $37^{\circ} \mathrm{C}$ for $30 \mathrm{~min}$ before being incubated in PBS-0.2\% BSA with the primary antibody anti-c-myc 9 E10 (1:100) at $37^{\circ} \mathrm{C}$ for $4 \mathrm{~h}$. The cells were washed twice with PBS before introducing peroxidase-conjugated rabbit anti-mouse IgG (1:1000). After one hour at room temperature, cells were extensively washed, and $100 \mu \mathrm{L}$ OPD (o-phenylene-diamine-dihydrochloride) reagent was added to each well. The reaction was stopped by addition of $250 \mu \mathrm{L}$ of $3 \mathrm{~N} \mathrm{HCl}$. The absorbance was measured at $492 \mathrm{~nm}$ on a plate-reader, and results were expressed in $492 \mathrm{~nm} \mathrm{OD} \times$ 1000/2000 L6 cells (mean of ten independent assays). L6 cells' integrity was preserved throughout all experiments, confirming the absence of extract potential toxicity. 


\subsubsection{Hepatic Glucose 6-Phosphatase (G6Pase) Activity Evaluation on Rat Microsomes}

The hepatic G6Pase assay was previously described [9]. Briefly, a hepatic microsome suspension of $10 \mu \mathrm{L}$ corresponding to $10 \mu \mathrm{g}$ of total proteins) was incubated for $30 \mathrm{~min}$ at $30{ }^{\circ} \mathrm{C}$ in a buffer $(100 \mu \mathrm{L})$ containing $20 \mathrm{mM}$ of glucose 6-phosphate. The effects of Oc and Mu extracts were studied at $50 \mathrm{mg} \mathrm{mL}^{-1}$. Positive control was NCRAE [11] at $50 \mathrm{mg} \cdot \mathrm{mL}^{-1}$.

The Pi product was determined with malachite green reagent and optical density reading at $660 \mathrm{~nm}$. Results are expressed in pmoles of inorganic phosphate produced during $1 \mathrm{~h}$ per $10 \mu \mathrm{g}$ of total proteins. A Triton X100 hepatic microsome treated was used as a control of microsomes' integrity. The acidification inhibition served as a negative control.

\subsubsection{Protective Evaluation of L6 Cells against $\mathrm{H}_{2} \mathrm{O}_{2}$ Oxidative Stress}

As previously described [11], L6-myoblasts cells were seeded at $10^{4}$ cells/well in 96well plates and cultured for 4 days in DMEM before changing for a DMEM supplemented with FCS cocktail medium and added with the different extracts at the final concentration of $50 \mu \mathrm{g} \cdot \mathrm{mL}^{-1}$ and cultured $12 \mathrm{~h}$ at $37{ }^{\circ} \mathrm{C}$ in a $5 \% \mathrm{CO}_{2}$ chamber. The next day, the cells were washed twice by $200 \mu \mathrm{L}$ of KRB- $0.1 \%$ BSA and then placed in the same buffer with or without $\mathrm{H}_{2} \mathrm{O}_{2}$ at $40 \mu \mathrm{M}$ for three hours to obtain $50-60 \%$ of mortality. The cells washed once by PBS were incubated $5 \mathrm{~min}$ in $100 \mu \mathrm{L}$ of Trypan-blue (Sigma-Aldrich) solution 1/3 diluted in PBS. Trypan-blue solution was discarded and the cell layers were visualized with a Stereo Zoom Microscope. The images were treated using Image 1.48v (Image Processing and Analysis in Java: http://imagej.nih.gov/ij/ (accessed on 31 January 2021)) software. The blue color was translated into black spots, and the densities of spots were calculated. The data are expressed as percentage of mortality.

\subsection{Data Analysis}

Statistical analyses were performed using analysis of variance. Data are expressed as mean \pm SD. Differences were considered statistically significant at $p<0.05\left(^{*}\right), p<0.01\left({ }^{* *}\right)$, or $\left.p<0.001{ }^{* * *}\right)$ using the Statgraphics $18^{\circledR}$ software.

\section{Conclusions}

In conclusion, the in vitro set of four biological tests, associated with extracts chemical composition analysis, could represent a step toward an alternative method for in vivo studies to use for rapid early screening of putative antidiabetic plant extracts collections. In addition to an obvious interest with regard to ethical animal care issues, a proper cluster of in vitro cellular bioassays focusing on key targets of type 2 diabetes physiopathology may contribute to the anticipation of in vivo pre-clinical therapeutic potential based on proper correlation between in vitro and in vivo results at both the pharmacological and toxicological levels.

In addition, such an optimized combination of in vitro biological tests may provide preliminary insights not only into the ratio of compounds necessary for an extract to produce significant bioactivity but also into the potential deleterious effects at cellular levels; as seen with $\mathrm{Mu}$. Finally, they could provide clues for bioguidance of the extraction process to adequately design plant extracts of therapeutic interest with a proper health benefit/risk ratio.

Further investigations are need to be conducted to integrate the influence of absorption on bioactivity and to confirm and consolidate our data on a larger range of plants.

Author Contributions: Conceptualization, D.T. and P.P.; in vitro experiments, glucose uptake, and oxidative stress, A.A., P.P., Y.A.I., F.L. and D.S.T.T.; insulin release experiment, K.F. and D.T.; HPLC analysis, A.S. and G.C.; LC-MS analysis, L.P.R.B. and G.C. All authors have read and agreed to the published version of the manuscript.

Funding: This research received no external funding.

Institutional Review Board Statement: Not applicable. 
Informed Consent Statement: Not applicable.

Data Availability Statement: All data are included on this paper.

Acknowledgments: We sincerely thank Gérard Ribes for consenting to give us precious scientific advice and for his help in the redaction of this publication.

Conflicts of Interest: The authors declare no conflict of interest and no financial interference with the IP rights of indigenous people.

Sample Availability: Samples and compounds are available from the authors.

\section{References}

1. Shoelson, S.E.; Herrero, L.; Naaz, A. Obesity, inflammation, and insulin resistance. Gastroenterology 2007, 132, 2169-2180. [CrossRef]

2. Robertson, R.P.; Harmon, J.; Tran, P.O.; Poitout, V. Beta-cell glucose toxicity, lipotoxicity, and chronic oxidative stress in type 2 diabetes. Diabetes 2004, 53 (Suppl. 1), S119-S124. [CrossRef] [PubMed]

3. Galicia-Garcia, U.; Benito-Vicente, A.; Jebari, S.; Larrea-Sebal, A.; Siddiq, H.; Uribe, K.; Ostolaza, H.; Martín, C. Pathophysiology of type 2 diabetes mellitus. Int. J. Mol. Sci. 2020, 21, 6275. [CrossRef] [PubMed]

4. Awwad, A.; Poucheret, P.; Idres, A.Y.; Bidel, L.; Tousch, D. The bitter Asteraceae: An interesting approach to delay the metabolic syndrome progression. NFS J. 2020, 18, 29-38. [CrossRef]

5. Fraisse, D.; Felgines, C.; Texier, O.; Lamaison, J.-L. Caffeoyl derivatives: Major antioxidant compounds of some wild herbs of the Asteraceae family. Food Nutr. Sci. 2011, 2, 181-192. [CrossRef]

6. Schlernitzauer, A.; Oiry, C.; Hamad, R.; Galas, S.; Cortade, F.; Chabi, B.; Casas, F.; Pessemesse, L.; Fouret, G.; Feillet-Coudray, C.; et al. Chicoric acid is an antioxidant molecule that stimulates AMP kinase pathway in L6 myotubes and extends lifespan in Caenorhabditis elegans. PLoS ONE 2013, 8, e78788.

7. Umeno, A.; Horie, M.; Murotomi, K.; Nakajima, Y.; Yoshida, Y. Antioxidative and antidiabetic effects of natural polyphenols and isoflavones. Molecules 2016, 21, 708. [CrossRef]

8. Tousch, D.; Lajoix, A.D.; Hosy, E.; Azay-Milhau, J.; Ferrare, K.; Jahannault, C.; Cros, G.; Petit, P. Chicoric acid, a new compound able to enhance insulin release and glucose uptake. Biochem. Biophys. Res. Commun. 2008, 377, 131-135. [CrossRef]

9. Tousch, D.; Bidel, L.P.; Cazals, G.; Ferrare, K.; Leroy, J.; Faucanié, M.; Chevassus, H.; Tournier, M.; Lajoix, A.D.; Azay-Milhau, J. Chemical analysis and antihyperglycemic activity of an original extract from burdock root (Arctium lappa). J. Agric. Food. Chem. 2014, 62, 7738-7745. [CrossRef]

10. Azay-Milhau, J.; Ferrare, K.; Leroy, J.; Aubaterre, J.; Tournier, M.; Lajoix, A.D.; Tousch, D. Antihyperglycemic effect of a natural chicoric acid extract of chicory (Cichorium intybus L.): A comparative in vitro study with the effects of caffeic and ferulic acids. J. Ethnopharmacol. 2013, 150, 755-760. [CrossRef]

11. Ferrare, K.; Bidel, L.P.R.; Awwad, A.; Poucheret, P.; Cazals, G.; Lazennec, F.; Azay-Milhau, J.; Tournier, M.; Lajoix, A.D.; Tousch, D. Increase in insulin sensitivity by the association of chicoric acid and chlorogenic acid contained in a natural chicoric acid extract (NCRAE) of chicory (Cichorium intybus) for an antidiabetic effect. J. Ethnopharmacol. 2018, 215, 241-248. [CrossRef] [PubMed]

12. Aguiyi, J.C.; Obi, C.I.; Gang, S.S.; Igweh, A.C. Hypoglycaemic activity of Ocimum gratissimum in rats. Fitoterapia 2000, 71, 444-446. [CrossRef]

13. Egesie, U.G.; Adelaiye, A.B.; Ibu, J.O.; Egesie, O.J. Safety and hypoglycaemic properties of aqueous leaf extract of Ocimum gratissimum in streptozotocin induced diabetic rats. Niger J. Physiol. Sci. 2006, 21, 31-35. [CrossRef] [PubMed]

14. Mohammed, A.; Tanko, Y.; Okasha, M.A.; Magaji, R.A.; Yaro, A.H. Effects of aqueous leaves extract of Ocimum gratissimum on blood glucose levels of streptozocin induced diabetic wistar rats. Afr. J. Biotechnol. 2007, 6, 2087-2090.

15. Okon, U.A.; Owo, D.U.; Udokang, N.E.; Udobang, J.A.; Ekpenyong, C.E. Oral administration of aqueous leaf extract of Ocimum gratissimum ameliorates polyphagia, polydipsia and weight loss in streptozotocin-induced diabetic rats. Am. J. Med. Med. Sci. 2012, 2, 45-49.

16. Nwogor, U.A. Effects of prolonged administration of aqueous extract of Ocimum gratissimum (Scent Leaf) on blood glucose and lipid profile in alloxan induced diabetic albino rats. Am. J. Biomed. Life Sci. 2016, 4, 30-34. [CrossRef]

17. Okoduwa, S.I.R.; Umar, I.A.; James, D.B.; Inuwa, H.M. Anti-diabetic potential of Ocimum gratissimum leaf fractions in fortified diet-fed streptozotocin treated rat model of type-2 diabetes. Medicines 2017, 11, 4-14. [CrossRef]

18. Ajayi, A.M.; Umukoro, S.; Ben-Azu, B.; Adzu, B.; Ademowo, O.G. Toxicity and protective effect of phenolic-enriched ethylacetate fraction of Ocimum gratissimum (Linn.) leaf against acute inflammation and oxidative stress in rats. Drug Dev. Res. 2017, 78, 135-145. [CrossRef] [PubMed]

19. Casanova, L.M.; da Silva, D.; Sola-Penna, M.; de Magalhães Camargo, L.M.; de Moura Celestrini, D.; Luzineide, W.T.; Soares, C.S Identification of chicoric acid as a hypoglycemic agent from Ocimum gratissimum leaf extract in a biomonitoring in vivo study. Fitoterapia 2014, 93, 132-141. [CrossRef]

20. Ajayi, G.O.; Igboekwe, N.A. Evaluation of anti-diabetic potential of the leaves of Musanga cecropioides R. Brown. Planta Med. 2013, 79, PE7. [CrossRef] 
21. Nyunaï, N.; Yaya, A.J.; Tabi, T.G.; Tchamgoue, A.; Ngondé, M.; Minka, C. Anti-hyperglycemic and antioxidant potential of water-ethanol extract of Musanga cecropioides stem bark. Int. J. Pharma. Sci. Drug Res. 2016, 8, 01. [CrossRef]

22. Adeneye, A.A.; Ajagbonna, O.P.; Ayodele, O.W. Hypoglycemic and antidiabetic activities on the stem bark aqueous and ethanol extracts of Musanga cecropioides in normal and alloxan-induced diabetic rats. Fitoterapia 2007, 78, 502-505. [CrossRef] [PubMed]

23. Adeneye, A.A.; Ajagbonna, O.P.; Adeleke, T.I.; Bello, S.O. Preliminary toxicity and phytochemical studies of the stem bark aqueous extract of Musanga cecropioides in rats. J. Ethnopharmacol. 2006, 105, 374-379. [CrossRef]

24. Adeneye, A.A.; Ajagbonna, O.P.; Mojiminiyi, F.B.; Odigie, I.P.; Ojobor, P.D.; Etarrh, R.R.; Adeneye, A.K. The hypotensive mechanisms for the aqueous stem bark extract of Musanga cecropioides in Sprague-Dawley rats. J. Ethnopharmacol. 2006, 106, 203-207. [CrossRef]

25. Sowemimoa, A.; Okwuchukua, E.; Samuel, F.M.; Ayoolaa, O.; Mutiata, I. Musanga cecropioides leaf extract exhibits antiinflammatory and anti-nociceptive activities in animal models. Rev. Brasil. Farmacog. 2015, 25, 506-512. [CrossRef]

26. Salawu, S.O.; Ogundare, A.O.; Ola-Salawu, B.B.; Akindahunsi, A.A. Antimicrobial activities of phenolic containing extracts of some tropical vegetables. Afric. J. Pharm. Pharmacol. 2011, 5, 486-492.

27. Lacaille-Dubois, M.A.; Franck, U.; Wagner, H. Search for potential angiotensin converting enzyme (ACE)-inhibitors from plants. Phytomedicine 2001, 8, 47-52. [CrossRef]

28. Ayinde, B.; Onwukaeme, D.N.; Omogbay, E.K. Isolation and characterization of two phenolic compounds from the stem bark of Musanga cecropioides R. Brown (Moraceae). Acta Pol. Pharma. 2017, 64, 183-185.

29. Venuprasad, M.P.; Hemanth, K.K.; Sakina, R.; Farhath, K. Phytochemical analysis of Ocimum gratissimum by LC-ESI-MS/MS and its antioxidant and anxiolytic effects. S. Afr. J. Bot. 2014, 92, 151-158. [CrossRef]

30. Rezzoug, M.; Bakchiche, B.; Gherib, A.; Roberta, A.; Guido, F.; Kilinçarslan, O.; Mammado, R.; Bardaweel, R.S. Chemical composition and bioactivity of essential oils and Ethanolic extracts of Ocimum basilicum L. and Thymus algeriensis Boiss. \& Reut. from the Algerian Saharan Atlas. BMC Complementary Altern. Med. 2019, 19, 146.

31. Pereira, C.A.M.; Yariwake, J.H.; McCullagh, M. Distinction of the C-glycosylflavone isomer pairs orientin/isoorientin and vitexin/isovitexin using HPLC-MS exact mass. Phytochem. Anal. 2005, 16, 295-301. [CrossRef]

32. Arion, W.J.; Canfield, W.K.; Ramos, F.C.; Su, M.L.; Burger, H.J.; Hemmerle, H.; Schubert, G.; Below, P.; Herling, A.W. Chlorogenic acid analogue S 3483: A potent competitive inhibitor of the hepatic and renal glucose-6-phosphatase systems. Arch. Biochem. Biophys. 1998, 351, 279-285. [CrossRef]

33. Meng, S.; Cao, J.; Feng, Q.; Peng, J.; Hu, Y. Roles of Chlorogenic acid on regulating glucose and lipids metabolism: A review. Evid.-Based Complementary Altern. Med. 2013, 201, 801457. [CrossRef]

34. Chiu, Y.W.; Lo, H.J.; Huang, H.Y.; Chao, P.Y.; Hwang, J.M.; Huang, P.Y.; Huang, S.J.; Liu, J.Y.; Lai, T.J. The antioxidant and cytoprotective activity of Ocimum gratissimum extracts against hydrogen peroxide-induced toxicity in human HepG2 cells. J. Food Drug Anal. 2013, 21, 253-260. [CrossRef]

35. Madunić, I.V.; Madunić, J.; Antunović, M.; Paradžik, M.; Garaj-Vrhovac, V.; Breljak, D.; Marijanović, I.; Gajski, G. Apigenin, a dietary flavonoid, induces apoptosis, DNA damage, and oxidative stress in human breast cancer MCF-7 and MDA MB-231 cells. Arch. Pharmacol. 2018, 391, 537-550. [CrossRef]

36. Seydi, E.; Rasekh, H.R.; Salimi, A.; Mohsenifar, Z.; Pourahmad, J. Selective toxicity of Apigenin on cancerous hepatocytes by directly targeting their mitochondria. Anti-Cancer Agents Med. Chem. 2016, 16, 11-22. [CrossRef]

37. Martucciello, S.; Masulo, M.; Cerulli, A.; Piacente, S. Natural products targeting ER stress, and the functional link to mitochondria. Int. J. Mol. Sci. 2020, 21, 1905. [CrossRef] [PubMed]

38. Babich, H.; Sedletcaia, A.; Kenigsberg, B. In Vitro cytotoxicity of protocatechuic acid to cultured human cells from oral tissue: Involvement in oxidative stress. Pharmacol. Toxicol. 2002, 91, 245-253. [CrossRef] [PubMed]

39. Villano, D.; Fernandez-Pachon, M.S.; Moya, M.L.; Troncoso, A.M.; Garcia-Parrilla, M.C. Radical scavenging ability of polyphenolic compounds towards DPPH free radical. Talanta 2007, 71, 230-235. [CrossRef]

40. Mezghenna, K.; Leroy, J.; Azay-Milhau, J.; Tousch, D.; Castex, F.; Gervais, S.; Delgado-Betancourt, V.; Gross, R.; Lajoix, A.D. Counteracting neuronal NO synthase proteasomal degradation improves glucose transport in insulin resistant skeletal muscle. Diabetologia 2014, 57, 177-186. [CrossRef]

41. Wang, Q.; Khayat, Z.; Kishi, K.; Ebina, Y.; Klip, A. GLUT4 translocation by insulin in intact muscle cells: Detection by a fast and quantitative assay. FEBS Lett. 1998, 427, 193-197. [CrossRef] 